\title{
IMPLIKASI ADANYA PEMALSUAN TANDA TANGAN DALAM AKTA JUAL BELI TANAH YANG DILAKUKAN OLEH PPAT
}

\author{
Edi Asrofin ${ }^{*}$, Umar Ma'ruf ${ }^{* *}$ \\ * Mahasiswa Program Magister (S2) Kenotariatan Fakultas Hukum UNISSULA, email : ediasrofin.sh@gmail.com \\ ${ }^{* *}$ Dosen Fakultas Hukum UNISSULA
}

\begin{abstract}
Not a few cases of falsified data that ends in the dispute often surfaced, both in print and electronic media and even non-publicized too much. Maybe in the short term, buyers do not face a lawsuit from another party, but in the long run the buyer will experience a lawsuit from another party who feels the rights to his land. Having a legal defect in a deed may result in the illegality of a later act of law. The problem of this thesis: why can there be counterfeiting of signatures in the deed of sale and purchase of land done by PPAT, how the process of handling the existence of signature falsification in the deed of sale and purchase of land done by PPAT and whether the implication of signature falsification of deed of sale and purchase of land done By PPAT.

The method used in this research is sociological juridical, specification of jurisdiction approach of analysis, data used primary data and secondary data. Problems are analyzed with the theory of legal protection and legal certainty.

The result of thesis research is known that the factors causing forgery of signatures in the deed of buying and selling of land conducted by PPAT PPAT have falsified the seller's signature in the process of making the Deed of Sale and Purchase, this is because PPAT assume that there has been signature from the seller in Receipt of previous buying and selling transaction so that it does not matter if in the Sale and Purchase Deed of the seller's signature in fake., The process of handling the signature fraud in the deed of sale and purchase of land conducted by PPAT is based on report from the seller who sued because felt the sign of the ladder in Fake in the Deed of Sale and Purchase, then the police conduct an investigation to the PPAT. The implication of counterfeiting the signatures of the land sale and purchase certificate conducted by PPAT may be criminalized, if it can be proven in court and Sanctions that could threaten PPAT which makes the deed inappropriate or indicated by the signature falsification in the document deed which is actually dismissal sanction with disrespect From his post.
\end{abstract}

Keywords: Counterfeiting, Signature, PPAT Batang

\section{PENDAHULUAN}

Jual beli tanah adalah perbuatan hukum yang berupa penyerahan hak milik (penyerahan tanah untuk selama-lamanya) oleh penjual kepada pembeli, yang pada saat itu juga menyerahkan harganya kepada penjual. $^{1}$ Dengan adanya

\footnotetext{
${ }^{1}$ Effendi Perangin. Hukum Agraria Di Indonesia (suatu telaah dari sudut pandang praktisi hukum). 1991. cetakan ketiga. Jakarta: Rajawali. Hal 13
}

ketentuan UUPA, jaul beli tanahh tidak lagi dibuat di hadapan Kepala Adat atau Kepalaa Desa secara bawah tangan, melainkan dihadapan seorang Pejabat Pembuat Akta Tanah (PPAT) atau Pejabat Pembuat Akta Tanah Sementara (PPAT Sementara) apabila suatu daerah Kecamatan belum diangkat seorang PPAT. Dan mereka diangkat oleh Kepala Badan Pertanahan Nasional Republik Indonesia, berdasarkan syarat-syarat tertentu. Keharusan jual beli tanah dihadapan PPAT atau PPAT Sementara, maka telah 
diterbitkan Peraturan Pemerintah Nomor 37 Tahun 1998 tentang Peraturan Jabatan Pejabat Pembuat Akta Tanah jo Peraturan Kepala Badan Pertanahan Nasional Nomor 1 Tahun 2006 tentang Kesatuan Pelaksanaan Peraturan Pemerintah Nomor 37 Tahun 1998 tentang Peraturan Jabatan Pejabat Pembuat Akta Tanah. Penerbitan peraturan tersebut dilakukan dalam rangka program pelayanan masyarakat dalam pembuatan akta PPAT.

Tidak sedikit kasus mengenai data-data yang dipalsukan yang berakhir pada sengketa sering mengemuka, baik di media cetak maupun elektronik dan bahkan yang tidak terpublikasikan pun banyak. Mungkin dalam jangka pendek, pembeli tidak mengalami gugatan dari pihak lain, tetapi dalam jangka panjang pembeli akan mengalami gugatan dari pihak lain yang merasa memiliki hak atas tanahnya. Dengan adanya cacat hokum pada suatu akta dapat menyebabkan tidak sahnya perbuatan hukum yang dilakukan kemudian. Berkaitan dengan hal tersebut, PPAT atau PPAT Sementara yang bersangkutan dapat melakukan pembelaan meskipun didalam ketentuan hukum tentang PPAT belum diatur mengenai hal tersebut; dengan adanya jaminan kebenaran yang diberikan oleh penghadap yang dimuat didalam akta tersebut sebagai akta partij (akta para pihak) yang sesuai dengan kehendak/keterangan yang telah diberikan dimana PPAT atau PPAT Sementara bukanlah pihak yang berwenang untuk melakukan penyidikan atas kebenaran dan keaslian dari identitas penghadap, melainkan bertindak berdasarkan bukti materiil yang telah lengkap yang diberikan kepadanya. Apabila PPAT atau PPAT Sementara dituntut oleh pihak ketiga yang merasa dirugikan ataupun diminta sebagai saksi di Pengadilan maka hal tersebut hanya sebatas dimintakan keterangan sehubungan akta yang dibuatnya, disamping itu PPAT atau PPAT Sementara pun dapat meminta perlindungan hukum/upaya pembelaan kepada IPPAT sebagai suatu organisasi profesi dimana ia bernaung. Berdasarkan uraian diatas maka penulis tertarik menulis dengan judul : "Implikasi Adanya Pemalsuan Tanda Tangan Dalam Akta Jual Beli Tanah Yang Dilakukan Oleh PPAT"

Adapun yang menjadi pokok permasalahan yang akan diteliti adalah Mengapa bisa terjadi pemalsuan tanda tangan dalam akta jual beli tanah yang dilakukan oleh PPAT ? Bagaimana proses penanganan terhadap adanya pemalsuan tanda tangan dalam akta jual beli tanah yang dilakukan oleh PPAT? Apakah Implikasi adanya pemalsuan tanda tangan akta jual beli tanah yang dilakukan oleh PPAT?

\section{METODE PENELITIAN}

Metode yang digunakan dalam penelitian ini adalah yuridis sosiologis, yaitu dalam penelitian ini Penulis melakukan peninjauan dari aspek hukumnya untuk mengetahui peraturan-peraturan yang berlaku khususnya yang berkaitan keterkaitan pemalsuan tanda tangan dalam akta jual beli tanah yang dilakukan oleh PPAT. Jenis dan sumber data berupa data primer dan data sekunder. Dalam penulisan tesis ini penulis menggunakan analisa data secara kualitatif yaitu suatu cara penelitian yang menghasilkan data secara deskriptif.

\section{PEMBAHASAN}

\section{Faktor-Faktor Penyebab Terjadi Pemalsuan Tanda Tangan Dalam Akta Jual Beli Tanah Yang Dilakukan Oleh PPAT}

Beberapa penyebab terhambatnya proses pensertipikatan hak atas tanah secara sporadik, masih ada penyebab lainnya, pemalsuan terhadap identitas pemegang hak yang dalam akta disebutkan "penghadap saya", artinya pemegang hak atas tanah yang dalam akta disebutkan sebagai penghadap PPAT, padahal identitas pemohon merupakan persyaratan pokok yang harus dipenuhi dari sekian banyak persyaratan pendaftaran tanah untuk memperoleh sertifikat hak atas tanah. Hal demikian akan menimbulkan permasalahan besar di kemudian hari yang melibatkan PPAT yang bersangkutan. PPAT dapat terseret ke dalam kasus-kasus hukum manakala terdapat hal-hal yang tidak sesuai dengan apa yang tercntum dalam akta, seperti : (1) tanggal di dalam akta tidak sesuai dengan kehadiran para pihak; (2) para pihak tidak hadir, tetapi ditulis hadir; (3) para pihak tidak membubuhi tanda 
tangan tetapi ditulis atau ada tanda tangannya; (4) akta sebenarnya tidak dibacakan tetapi diterangkan telah dibacakan; (5) luas tanah berbeda dengan yang diterangkan oleh para pihak, (6) PPAT ikut campur tangan terhadap syaratsyarat perjanjian; (7) pencantuman dalam akta bahwa pihak-pihak sudah membayar lunas apa yang diperjanjikan padahal sebenarnya belum lunas atau bahkan beluum ada pembayaran secara riil; (8) pencantuman pembacaan akta yang harus dilakukan oleh PPAT sendiri, padahal tidak dilakukan; (9) pencantuman mengenal orang yang menghadap padahal sebenarnya tidak mengenalnya

\section{Proses Penanganan Terhadap Adanya Pemalsuan Tanda Tangan Dalam Akta Jual Beli Tanah Yang Dilakukan Oleh PPAT}

Dari kasus dimana pihak penjual mengetahui bahwa telah dikeluarkannya AJB tetapi pihak penjual merasa tidak dimintai tanda tangan oleh PPAT, sehingga pihak penjual merasa bahwa tanda tangan yang ada di AJB tersebut palsu atau telah dipalsukan oleh PPAT. Kemudian pihak penjual menggugat karena merasa tidak pernah tandattangan di akta jual beli (AJB) dan melaporkan ke kantor polisi, selang beberapa hari dari pihak kepolisian melakukan penyelidikan, dan pihak kepolisian mulai memanggil beberapa pihak yang terkait.

Pemberitahuan dimulainya penyidikan dilakukan dengan SPDP (Surat Pemberitahuan Dimulainya Penyidikan), yang dilampiri :

- Laporan polisi

Laporan polisi dibuat ketika pihak pertama yang merasa tandatangannya dipalsu melaporkan ke polisi.

- Resume BAP saksi

Berdasarkan BAP Laporan dari Penggugat tentang Pemalsuan tanda tangan, maka kepolisian memanggil beberapa saksi yang berkaitan dengan kasus pemalsuan tanda tangan. BAP Saksi dibuat berdasarkan keterangan-keterangan saksi yang berkaitan dengan kasus pemalsuan tanda tangan yang dilakukan oleh PPAT $X$.

- Resume BAP Tersangka

Berdasarkan keterangan dari saksi-saksi yang telah tertuang dalam BAP saksi maka kepolisian membuat resume BAP tersangka.

- Berita acara penangkapan

Dengan telah ditetapkan tersangka kasus pemalsuan tanda tangan oleh PPAT $\mathrm{X}$, maka pihak kepolisian membuat berita acara penangkapan.

- Berita acara penahanan

Setelah berita acara penangkapan dibuat maka dibuatlah berita acara penangkapan PPAT $X$.

- Berita acara penggeledahan

Dengan adanya berita acara penahanan PPAT X, pihak kepolisian melakukan pengeledahan tempat PPAT $\mathrm{x}$ berdasarkan berita acara penggeledahan untuk mencari barang-barang bukti yang berkaitan dengan kasus pemalsuann tanda tangan.

- Berita acara penyitaan.

Setelah dilakukan pengeledahan dan di temukan bukti-bukti, maka kepolisian membuat berita acara penyitaaan.

Implikasi Adanya Pemalsuan Tanda Tangan Akta Jual Beli Tanah Yang Dilakukan Oleh PPAT

Sanksi yang dapat mengancam PPAT yang membuat akta tidak sesuai atau terindikasi adanya pemalsuan tanda tangan dalam akta dokumen yang sebenarnya adalah sanksi pemberhentian dengan tidak hormat dari jabatannya. Akibat adanya pemalsuan tanda tangan memiliki adalah :

1. PPAT tersebut bisa di pecat dan bisa tidak karena sekarang PPAT $(\mathrm{X})$ tersebut masih proses dalam persidangan di Batang

2. Akibat aktanya untuk aktanya tersebut bisa dibatalkan karena dalam akta tersebut terdapat tanda tangan palsu yang ditandatangani oleh $\operatorname{PPAT}(\mathrm{X})$.

\section{PENUTUP}

\section{Simpulan}

Dari paparan yang telah penulis uraikan pada bab sebelumnya maka penulis dapat mengambil beberapa simpulan sebagai berikut :

1. Faktor-faktor sebab terjadi pemalsuan tanda tangan dalam akta jual beli tanah yang 
dilakukan Oleh PPAT yaitu PPAT telah memalsukan tanda tangan penjual dalam proses pembuatan Akta Jual Beli, hal ini disebabkan karena PPAT menganggap bahwa telah ada tanda tangan dari penjual dalam kuitansi jual beli sebelumnya sehingga menganggap tidak masalah jika dalam Akta Jual Beli tanda tangan pihak penjual di palsukan.,

2. Proses penanganan terhadap adanya pemalsuan tanda tangan dalam akta jual beli tanah yang dilakukan oleh PPAT yaitu berdasarkan laporan dari pihak penjual karena merasa tanda tangga di palsukan dalam Akta Jual beli, maka pihak kepolisian melakukan penyelidikan ke pihak PPAT.

3. Implikasi adanya pemalsuan tanda tangan akta jual beli tanah yang dilakukan oleh PPAT bisa saja dihukum pidana, jika dapat dibuktikan dipengadilan dan Sanksi yang dapat mengancam PPAT yang membuat akta tidak sesuai atau terindikasi adanya pemalsuan tanda tangan dalam akta dokumen yang sebenarnya adalah sanksi pemberhentian dengan tidak hormat dari jabatannya.

\section{Saran-saran}

Saran-saran yang dapat disampaikan dalam penelitian tesis ini adalah sebagai berikut :

1. Dalam membuat akta jual beli diharapkan seorang PPAT maupun notaris diharapkan bersikap profesional dalam menjalankan tugas dan kewajibannya.

2. Pembuatan akta jual beli merupakan akta yang otentik maka masyarakat di wajibkan mematuhi hukum dan tidak melakukan perbuatan tindak pidana.

3. Perlunya kerjasama dari masyarakat jika terindikasi atau ditemukannya dugaan pemalsuan tanda tangan dalam dokumen akta yang dikeluarkan oleh PPAT bisa melalui website resmi BPN.

\section{Daftar Pustaka}

\section{Buku-buku :}

Abdul Ghofur Anshori, Lembaga Kenotariatan Indonesia Perspektif Hukum dan Etika,
(Yogyakarta: UII Press, 2009)

Abdul Kadir Muhammad, Etika Profesi Hukum, (Bandung: PT. Citra Aditya Bakti, Cetakan ke III 2006)

Adjie, Habib. (2008). Hukum Notaris Indonesia. Bandung: Refika Aditama.

(2011). Kebatalan dan Pembatalan Akta Notaris. Bandung: Refika Aditama.

(2011). Majelis Pengawas Notaris. Bandung: Refika Aditama

Adami Chazawi, (2001), Kejahatan Terhadap Pemalsuan, Rajawali Pers, Jakarta

Anshori, Ghofur. (2009). Hukum Pidana Indonesia. Yogyakarta: UII Press.

Barda Nawawie Arief, (2010) Perkembangan AsasAsas Hukum Pidana Indonesia, (Perspektif Perbandingan Hukum Pidana), Badan Penerbit UNDIP Semarang

Effendi, Erdianto. (2011). Hukum Pidana Indonesia. Bandung: Refika Aditama.

Harahap, Yahya. (2012). Pembahasan Permasalahan dan Penerapan KUHAP. Jakarta: Sinar Grafika

Ira Koesoemawati dan Yunirman Rijan (2009), Ke Notaris, Jakarta : Raih Asa Sukses

Komar Andasasmita, (1981) Notaris I, Bandung : Sumur Bandung

Liliana Tedjosaputro, (1991), Malpraktek Notaris dan Hukum Pidana, Semarang : CV. Agung.

Lamintang, (1997) Dasar-Dasar hukum Pidana Indonesia, Bandung : Citra Aditya Bakti

Marpaung, Laden. (2011). Proses Penanganan Perkara Pidana. Jakarta: Sinar Grafika

Miru, Ahmadi (2007). Hukum Kontrak dan Perancangan Kontrak. Jakarta: Raja Grafindo Persada.

Moeliatno, (2000). Asas - Asas Hukum Pidana Indonesia, Jakarta : Rieneka Cipta.

R. Soegondo, Notodisoerjo, (1982) Hukum Notariat di Indonesia suatu, Penjelasan, Jakarta: 
Rajawali

Roesnantiti Prayitno,(1989) Tugas dan Tanggung Jawab Notaris sebagai Pejabat Pembuat Akta Tanah, Jakarta : Media Notariat INI

Soesilo, R. (1988). Kitab Undang - Undang Hukum Pidana. Bogor: Politeia.

Sri Sumarwani, (2005) Tindak Pidana Baru Dalam RUU KUHP 2005, Disampaikan Dalam Diskusi Intern Tim Pengembangan Iptek, UNISSULA, Semarang

SR. Sianturi, (1996), Asas-asas Hukum Pidana Di Indonesia dan Penerapannya, Alumni AhaemPetehaem, Jakarta.

Sudarto, (1990), Hukum Pidana I, Yayasan Sudarto Fakultas Hukum Undip, Semarang

Sudikno Mertokusumo, (1982), Hukum Acara Perdata di Indonesia, (Liberty, Yogyakarta

Subekti, (1984) Pokok-Pokok Hukum Perdata, PT. Intermesa, Cetakan ke XVIII, Jakarta

Tan Thong Kie, (2000), Studi Notariat-Serba Serbi Praktek Notaris, Ichtiar Baru Van Hoeve, Jakarta

Tongat,(2001) Pidana Kerja Sosial dalam Pembaharuan Hukum Pidana Indonesia,
Jakarta: Djambatan.

Tongat, (2008) Dasar-Dasar Hukum Pidana Indonesia Dalam Perspektif Pembaharuan, Penerbit : UMM Press, Malang

\section{Internet :}

Majalah Renvoi. edisi delapan pulud dua (Maret). JURNAL RENVOI MEDIATAMA. 2010.

Http//Adln.Lib.unair.ac.id, Lanny Kusumawati, Tanggung Jawab Jabatan Notaris.

www. Google search "Harkat dan Martabat Notaris".co.id

Ensiklopedi hukum pidana islam, Bab I Hakikat Tindak Pidana

Perundang-Undangan :

Undang-Undang dasar 1945

Kitab Undang-undang Hukum Perdata

Undang-undang Nomor 30 Tahun 2004 tentang Jabatan Notaris.

Undang-Undang Nomor 2 Tahun 2014 tentang Perubahan Undang-undang Nomor 30 Tahun 2004 tentang Jabatan Notaris

Peraturan Pemerinth No. 24 Tahun 2016 tentang PPAT 